\title{
PROGRAM PERAWATAN MULTIDISIPLIN DAN TERINTEGRASI UNTUK MENINGKATKAN KUALITAS PERAWATAN PASIEN DENGAN CHRONIC KIDNEY DISEASE
}

\author{
Ratna W. Rosyida ${ }^{1}$, M.G.A Putra ${ }^{2}$, Sa'bani N. A ${ }^{3}$, Ruly A. $S^{4}$ \\ ${ }^{1,2,3,4}$ Magister Keperawatan, Fakultas Kedokteran, Kesehatan Masyarakat, dan \\ Keperawatan Universitas Gadjah Mada, Yogyakarta \\ Email: ${ }^{1}$ ratna.w.r@mail.ugm.ac.id, \\ ${ }^{2}$ muhammadputraga1805@gmail.com, ${ }^{3}$ sabani.nur.a@mail.ugm.ac.id, \\ ruly_anita@yahoo.com
}

\begin{abstract}
ABSTRAK
Prevalensi penyakit ginjal kronis atau Chronic Kidney Disease (CKD) terus meningkat sepanjang tahun. Diperlukan suatu perawatan multidisiplin dan terintegrasi untuk meningkatkan outcome kesehatan pada pasien CKD. Studi ini bertujuan untuk mencari berbagai bukti terkait manfaat perawatan multidisiplin dan terintegrasi terhadap kualitas perawatan pada pasien pada pasien CKD. Pencarian literatur mengikuti flowchart PRISMA dan menggunakan 3 database yaitu Sciencedirect, Pubmed, dan SAGE. Artikel dipilih sesuai dengan kriteria inklusi yang sudah ditentukan dan eligibilitas artikel dianalisis menggunakan JBI Critical Appraisal Tools. Didapatkan sebanyak 5 artikel yang membahas mengenai perawatan multidisiplin atau perawatan terintegrasi pada pasien dengan CKD. Dari hasil studi didapatan kesimpulan bahwa perawatan secara multidisiplin dan terintegrasi meningkatkan outcome kesehatan berupa penurunan progresivitas CKD, penurunan RRT, cost effectiveness, penurunan kadar HbA1c, hospitalisasi, meningkatkan kesiapan dialisis dan survival pasien, namun tidak memberikan manfaat besar terhadap kontrol metabolik mineral pada pasien
\end{abstract}

Kata kunci: Integrasi, Multidisiplin, Penyakit ginjal kronis, Perawatan

\begin{abstract}
Prevalence of Chronic Kidney Disease (CKD) increased throughout the year. Multidisciplinary and integrated care was needed to improve the health outcomes of CKD patients. This study aims to find evidence related to the benefits of multidisciplinary and integrated care for the quality of care in CKD patients. The literature search followed the PRISMA flowchart and used 3 databases ie ScienceDirect, Pubmed, and SAGE. Articles were selected according to predefined inclusion criteria and articles eligibility were analyzed using JBI Critical
\end{abstract}


Appraisal Tools. There were 5 articles covering multidisciplinary care or integrated care in patients with CKD. The results of the study, it was concluded that multidisciplinary and integrated care decreased progression of $\mathrm{CKD}$, decreased RRT, cost-effectiveness, decreased HbAlc levels, hospitalization, improved dialysis and patient survival, but did not provide substantial benefit to the metabolic control of minerals in patients.

Keywords : Care, chronic kidney disease, integrated, multidisciplinary

\section{PENDAHULUAN}

Chronic Kidney Disease (CKD) merupakan masalah kesehatan masyarakat global dengan tingkat prevalensi dan insidensi yang terus meningkat, Diabetes dan hipertensi menjadi penyebab utama $C K D$ di semua negara yang berpenghasilan tinggi, menengah, maupun rendah. Insiden, prevalensi, dan perkembangan $C K D$ juga bervariasi di berbagai negara (Webster dkk., 2017). Menurut WHO, 864.226 kematian (1\%$5 \%$ ) di seluruh dunia disebabkan oleh $C K D$ pada tahun 2012. Selain itu $C K D$ menduduki peringkat keempat belas dalam daftar penyebab utama kematian dimana $C K D$ menyumbang 12.2 kematian per 100.000 orang. Proyeksi angka kematian dari $C K D$ akan terus meningkat hingga mencapai 14 per 100.000 orang pada tahun 2030. (World Health Organization, 2015).

Prevalensi $C K D$ akan meningkat seiring dengan bertambahnya umur. Di Indonesia, provinsi dengan prevalensi tertinggi adalah Sulawesi Tengah sebesar 0,5\%, diikuti Aceh, Gorontalo, dan Sulawesi Utara masing-masing 0,4 \% (Badan Penelitian dan Pengembangan Kesehatan, 2013). Berdasarkan hal tersebut, perlu perawatan yang komprehensif pada pasien dengan $C K D$ salah satunya dengan program perawatan multidisiplin dan terintegrasi.
Program perawatan multidisiplin melibatkan berbagai macam profesi kesehatan, sehingga dibutuhkan koordinasi serta keterlibatan antar anggota tim dalam pelaksanaannya untuk memberikan kualitas pelayanan yang maksimal pada pasien. Salah satu penelitian besar yang melibatkan pasien usia lanjut dengan $C K D$ menunjukkan hasil adanya penurunan sebesar $50 \%$ dalam penyebab kematian yang dirawat oleh tim multidisipliner dibandingkan dengan pasien non-multidisipliner (Hemmelgarn dkk., 2007). Tujuan dari perawatan multidisiplin antara lain dapat mengurangi tingkat penurunan fungsi ginjal yang tersisa, mengelola sekuel biokimia dan klinis $C K D$, serta mendidik pasien (Friedman dan Goldstein, 2008).

Perawatan terintegrasi merupakan bentuk asuhan komprehensif yang melibatkan multidisiplin dan beberapa setting pelayanan. Salah satu penelitian menunjukkan hasil bahwa perawatan yang dilakukan secara terintegrasi atau komprehensif oleh praktisi perawat yang diawasi oleh ahli nefrologi dapat mengurangi penurunan fungsi ginjal dan meningkatkan kondisi ginjal pada pasien CKD (Peeters dkk., 2014). Pada literature review ini, kami ingin mengetahui dampak perawatan multidisiplin dan terintegrasi terhadap kualitas perawatan pada pasien $C K D$. 


\section{METODE PENELITIAN}

Desain studi ini adalah literature review dengan prosedur tahapan studi pustaka untuk praktisi. Pertanyaan studi dirumuskan untuk mengetahui pengaruh perawatan multidisiplin terhadap outcome pada pasien CKD.Kata kunci yang digunakan adalah 'Chronic Kidney Disease 'AND 'Multidisciplinary 'AND' Care 'AND' Outcome'. Telusur dilakukan pada 3 databaseonline yaitu: SAGE, Pubmed, dan Sciencedirect. Kriteria inklusi dalam studi ini adalah artikel yang dipublikasi dalam rentang 2008-2018, tertulis dalam bahasa inggris, tersedia dan dapat diakses keseluruhan artikel, merupakan original research dengan berbagai desain penelitian. Artikel akan diekslusi apabila artikel tidak menggunakan bahasa inggris, tidak sesuai dengan tujuan dan rumusan masalah. Fokus studi menitikberatkan pada perawatan multidisiplin dan terintegrasi terhadap pasien usia dewasa hingga lansia yang disebabkan oleh Chronic Kidney Disease.

Pengkajian kualitas evidence untuk menentukan eligibilitas konten dilakukan critical appraisal dengan menggunakan The Joanna Briggs Institute Critical Appraisal Tools (2016). Seleksi artikel sesuai dengan tahapan ditampilkan dalam PRISMA flowcart pada Gambar 1. Adapun ekstraksi menghasilkan rangkuman yang mencakup penulis dan tahun penelitian, intervensi, outcome, desain dan partisipan.

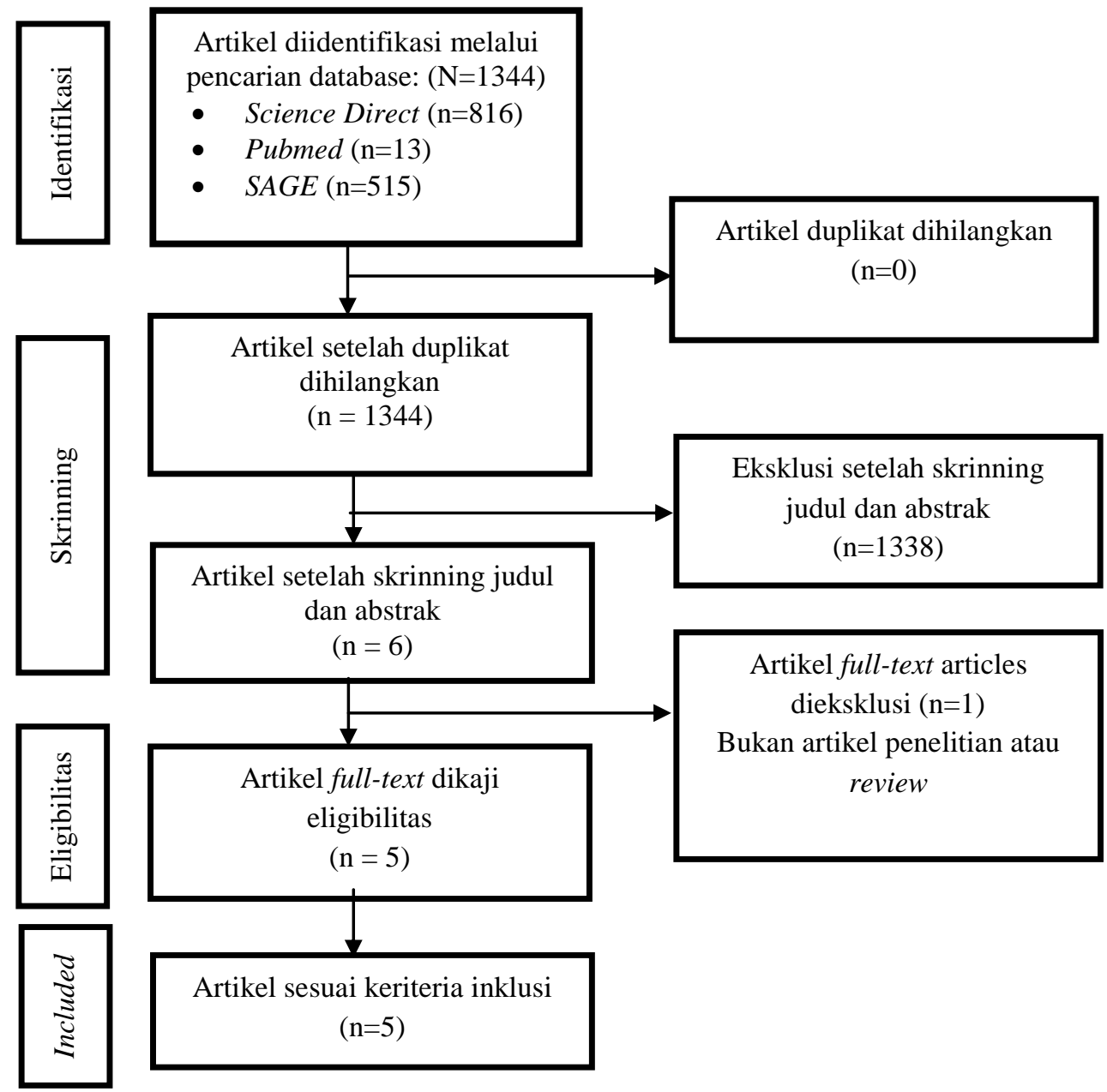

Gambar 1. Flowchart PRISMA. 


\section{HASIL DAN PEMBAHASAN}

Dari tiga database yang digunakan, ditemukan 6 artikel yang sesuai dengan pertanyaan penelitian (1 artikel dari SAGE, 4 artikel dari Pubmed dan 1 artikel dari Sciencedirect). Berdasarkan kriteria inklusi, peneliti memilih 5 jurnal yang memenuhi kriteria. Satu artikel dieksklusi karena bukan merupakan artikel penelitian original. Ekstrasi data artikel dapat dilihat pada Tabel 1.

Artikel-artikel tersebut juga telah memenuhi kriteria berdasarkan critical appraisal menggunakan Joana Briggs Institute Critical Appraisal Tools 2016. Kelima artikel penelitian tersebut berlokasi penelitian di negara Kanada, Swedia, Thailand, Taiwan dan Inggris. Populasi yang dipilih pada kelima artikel merupakan pasien penyakit ginjal kronis. Dua diantara 5 artikel menggunakan populasi pasien yang menjalani program terapi hemodialisis, sedangkan 3 artikel menggunakan populasi pasien yang menjalani terapi rawat jalan. Jenis intervensi yang digunakan pada kelima artikel tersebut berbasis perawatan multidisipliner. Dua dari kelima artikel meneliti perawatan dalam setting klinik multidisipliner yang telah tersedia di rumahsakit seperti pada artikel Friedman dkk. (2008) dan Fenton dkk. (2010).

Ketiga artikel lainnya secara terprogram mengadakan perawatan multidisiplin khusus untuk penelitiannya seperti pada artikel Pagels dkk. (2015), Jiamjariyapon dkk. (2017), Chen dkk. (2015). Tenaga kesehatan yang dilibatkan dalam kelima penelitian tersebut diantaranya diabetologis, nefrologis, perawat edukator, perawat spesialis pre dialisis, ahli gizi, apoteker, pekerja sosial dan fisioterapis. Tindakan yang dilakukan selama perawatan multidisipliner diantaranya edukasi, diskusi kelompok, pengaturan gejala klinis, pemeriksaan fisik, pemeriksaan laboratorium, konseling gizi, latihan perawatan diri, dan konseling pre-dialisis (Chen dkk., 2015; Fenton dkk., 2010; Jiamjariyapon dkk., 2017; Pagels dkk., 2015). Namun, untuk tingkat kontrol metabolik mineral belum dapat mengalami perubahan (Friedman dan Goldstein., 2008).

Program perawatan multidisiplin memberikan banyak manfaat dalam meningkatkan outcome kesehatan pada pasien dengan kidney disease. Jiamjariyapon dkk. (2017) membuktikan bahwa perawatan multidisiplin terintegrasi dapat memperlambat progresivitas $C K D$. Tim multidisplin klinik meliputi dokter spesialis, perawat, farmasi, ahli gizi, dan fisioterapi, sedangkan multidisiplin komunitas melibatkan perawat komunitas, volunteer, dan keluarga pasien. Namun hasil penelitian ini dapat diaplikasikan dengan baik jika sistem pelayanan kesehatan sudah terintegrasi dengan baik antara sistem pelayanan klinis dan komunitas.

Chen dkk. (2015)menyatakan bahwa pemberian intervensi dengan melibatkan tim multidisiplin dapat menurunkan tingkat kejadian Renal Replacement Therapy pada pasien dengan Advanced Chronic Kidney Disease sekaligus menurunkan biaya perawatan bagi pasien melalui penurunan masa hospitalisasi, kebutuhan emergency, dan kebutuhan dialisis. Tim multidisiplin pelayanan klinik meliputi spesialis nefrologi, perawat, ahli gizi, dan farmasi yang bekerjasama memberikan perawatan untuk meningkatkan outcome kesehatan pasien.

Pagels dkk. (2015) membuktikan bahwa multidimensional support program (MSP) dengan pendekatan multidisiplin pada pasien dengan Diabetic Kidney Disease efektif menurunkan HbAlc. Tim multidisiplin meliputi perawat (ahli diabetes dan endokrin), spesialis diabetes, spesialis nefrologi, ahli gizi, dan fisioterapi. Pasien diberikan edukasi, skill 
Tabel 1. Ekstraksi Data Artikel

\begin{tabular}{|c|c|c|c|c|}
\hline Author & Outcome & Design & Population \& Sample & Intervention \\
\hline $\begin{array}{l}\text { Friedman } \\
\text { dkk. } \\
(2008)\end{array}$ & $\begin{array}{l}\text { Kontrol } \\
\text { metabolisme } \\
\text { mineral pada } \\
\text { saat inisiasi } \\
\text { dialisis dan } \\
\text { pada tahun } \\
\text { pertama } \\
\text { sesudahnya }\end{array}$ & $\begin{array}{l}\text { Retrospecti } \\
\text { ve Cohort } \\
\text { Study }\end{array}$ & $\begin{array}{l}151 \text { pasien diklasifikasikan } \\
\text { berdasarkan penerimaan } \\
\text { MDC sebelum memulai } \\
\text { dialisis. } \\
67 \text { pasien menerima MDC } \\
\text { dan } 84 \text { pasien menerima } \\
\text { perawatan konvensional. }\end{array}$ & $\begin{array}{l}\text { Klinik Multidiciplinary } \\
\text { Predialysis Care (MDC) } \\
\text { dilakukan oleh ahli gizi, } \\
\text { nefrologis, perawat } \\
\text { edukator, apoteker dan } \\
\text { pekerja sosial. }\end{array}$ \\
\hline $\begin{array}{l}\text { Pagels } \\
\text { dkk. } \\
(2015)\end{array}$ & $\begin{array}{l}\text { Pengetahuan, } \\
\text { keterampilan } \\
\text { dan motivasi } \\
\text { pasien dengan } \\
\text { penyakit } \\
\text { ginjal } \\
\text { diabetes. }\end{array}$ & $\begin{array}{l}\text { Non- } \\
\text { randimized } \\
\text { Quasi } \\
\text { Experimen } \\
\text { tal Design }\end{array}$ & $\begin{array}{l}58 \text { pasien CKD yang } \\
\text { dirawat di klinik rawat jalan } \\
\text { ginjal }\end{array}$ & $\begin{array}{l}\text { Multi-dimensional Support } \\
\text { Programmer } \\
\text { dipimpin oleh perawat dan } \\
\text { memiliki pendekatan } \\
\text { multidisiplin, melibatkan } \\
\text { seorang diabetologist, } \\
\text { nephrologist, ahli gizi dan } \\
\text { fisioterapis. }\end{array}$ \\
\hline $\begin{array}{l}\text { Jiamjariy } \\
\text { apon dkk. } \\
(2017)\end{array}$ & $\begin{array}{lr}\text { Progesi } & \text { CKD } \\
\text { dari } & \text { nilai } \\
\text { eGFR, } & \\
\text { HbA1c, } & \text { urin } \\
\text { sodium } & 24 \\
\text { jam } & \text { dan } \\
\text { protein. } & \end{array}$ & $\begin{array}{l}\text { Cluster } \\
\text { Randomize } \\
d \text { Control } \\
\text { Trial }\end{array}$ & $\begin{array}{l}\text { Sebanyak } 586 \text { yang dikaji } \\
\text { untuk eligibiltas, } 442 \\
\text { partisipan secara random } \\
\text { dipilih dalam penelitian. }\end{array}$ & $\begin{array}{l}\text { Kelompok } \\
\text { menerima } \\
\text { standar, medikasi, dan } \\
\text { program edukasi. } \\
\text { Kelompok intervensi } \\
\text { menerima } \\
\text { standar, medikasi, dan } \\
\text { program edukasi, serta } \\
\text { menerima perawatan CKD } \\
\text { terintegrasi } \\
(\text { Multidiciplinary } \\
\text { Team). Care } \\
\end{array}$ \\
\hline $\begin{array}{l}\text { Chen } \\
\text { dkk. } \\
(2015)\end{array}$ & $\begin{array}{l}\text { Outcome } \\
\text { ginjal (nilai } \\
\text { eGFR, fosfat) } \\
\text { dan survival } \\
\text { pasien } \\
\text { (mulainya } \\
\text { dialisis, biaya) }\end{array}$ & $\begin{array}{l}\text { Retrospecti } \\
\text { ve } \\
\text { Observatio } \\
\text { nal Cohort } \\
\text { without } \\
\text { Randomiza } \\
\text { tion }\end{array}$ & $\begin{array}{l}\text { Sebanyak } 1382 \text { pasien CKD } \\
\text { dilibatkan dalam penelitian. } \\
592 \text { pasien menerima } \\
\text { perawatan multidisiplin dan } \\
614 \text { pasien tidak menerima } \\
\text { perawatan multidisiplin. }\end{array}$ & $\begin{array}{l}\text { Program multidisiplin: } \\
\text { Perawatan yang dilakukan } \\
\text { secara terintegrasi oleh } \\
\text { spesialis nefrologi, perawat, } \\
\text { ahli gizi, dan farmasi. } \\
\text { Perawat berperan } \\
\text { melakukan edukasi, ahli } \\
\text { gizi melakukan konsultasi } \\
\text { gizi. }\end{array}$ \\
\hline $\begin{array}{l}\text { Fenton } \\
\text { dkk. } \\
(2010)\end{array}$ & $\begin{array}{l}\text { Outcome } \\
\text { pasien dengan } \\
\text { CKD (Hb, } \\
\text { serum } \\
\text { albumin, } \\
\text { kalsium, } \\
\text { fosfat, tekanan } \\
\text { darah, } \\
\text { mulainya } \\
\text { dialisis, } \\
\text { admisi) }\end{array}$ & $\begin{array}{l}\text { Retrospecti } \\
\text { ve Case } \\
\text { Control } \\
\text { Study }\end{array}$ & $\begin{array}{l}\text { Kelompok MDC sebanyak } \\
171 \text { pasien, sedangkan } \\
\text { kelompok nefrologi } \\
\text { sebanyak } 194 \text { pasien. }\end{array}$ & 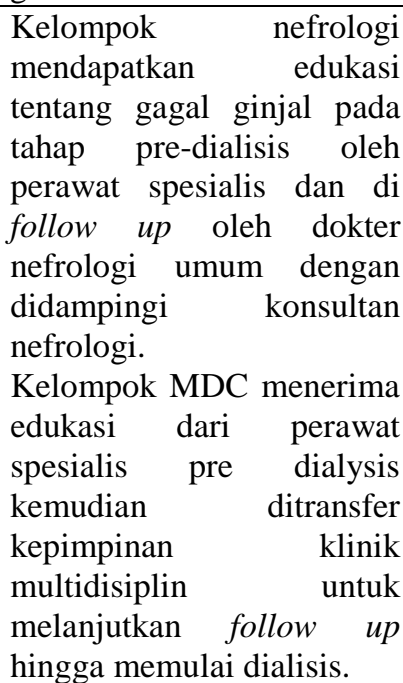 \\
\hline
\end{tabular}


training dan motivasi sebagai upaya promosi kesehatan dan self management, namun follow up dalam penelitian ini dilakukan dalam waktu singkat yaitu 4 bulan.

Fenton dkk. (2010) menyatakan bahwa tim multidisiplin (perawat, spesialis nefrologi, ahli gizi, social worker, dan ahli terapi okupasi ginjal) memberikan efek yang signifikan terhadap kesiapan pasien untuk dialisis, hospitalisasi lebih sedikit setelah dialisis, dan tingkat survival pasien lebih tinggi dibandingkan pemberian perawatan tradisional di klinik nefrologi. Program perawatan multidisplin tidak selalu memberikan dampak yang signifikan terhadap outcome kesehatan pasien CKD. Hasil yang berbeda didapatkan dari Friedman dkk. (2008) yang menyatakan bahwa perawatan multidisiplin (spesialis nefrologi, perawat, ahli gizi, farmasi, social worker, dan volunteer) tidak memberikan dampak yang signifikan terhadap kontrol metabolik mineral pada pasien yang akan menjalani dialisis hingga 1 tahun setelahnya. Penelitian ini dilakukan secara retrospektif sehingga confounding factor sulit diminimalkan.

Literature review ini memiliki beberapa keterbatasan yaitu sumber artikel yang digunakan berjumlah sedikit karena keterbatasan penelitian yang membahas mengenai perawatan multidisiplin dan terintegrasi pada penyakit gagal ginjal kronis, database yang digunakan terbatas hanya berjumlah 3 , dan desain penelitian berbeda-beda setiap artikel sehingga data yang diperoleh tidak homogen.

\section{KESIMPULAN}

Perawatan multidisiplin dan terintegrasi akan memperbaiki outcome pada pasien dengan CKD. Tim multidisiplin yang dapat dilibatkan yaitu dokter, perawat, farmasi, ahli gizi, dan fisioterapi yang akan berintegrasi dengan tim di komunitas yang meliputi perawat komunitas, volunteer, pekerja sosial, dan keluarga pasien. Manfaat yang diperoleh dengan perawatan multidisiplin dan terintegrasi yaitu dapat memperlambat progresivitas $C K D$, menurunkan $R R T$, cost effectiveness, menurunkan kadar HbA1c, menurunkan hospitalisasi, meningkatkan kesiapan dialisis dan survival pasien, namun tidak memberikan manfaat besar terhadap kontrol metabolik mineral pada pasien.

\section{DAFTAR PUSTAKA}

Badan Penelitian dan Pengembangan Kesehatan. (2013). Riset Kesehatan Dasar (RISKESDAS) 2013. Laporan Nasional 2013, 1-384. https://doi.org/ diakses 1 Desember 2013.

Chen, P. M., Lai, T. S., Chen, P. Y., Lai, C. F., Yang, S. Y., Wu, V. C., ... Tsai, T. J. (2015). Multidisciplinary care program for advanced chronic kidney disease: Reduces renal replacement and medical costs. American Journal of Medicine, 128(1), 68-76. https://doi.org/10.1016/j.amjmed.2014.07.042.

Fenton, A., Sayar, Z., Dodds, A., \& Dasgupta, I. (2010). Multidisciplinary care improves outcome of patients with stage 5 chronic kidney disease. Nephron Clinical Practice, 115(4). https://doi.org/10.1159/000313487.

Friedman, O., \& Goldstein, M. B. (2008). The Impact of Prior Multidisciplinary Predialysis Care on Mineral Metabolic Control among Chronic Hemodialysis Patients. Nephron Clin Pract. https://doi.org/10.1159/000167870.

Hemmelgarn, B. R., Manns, B. J., Zhang, J., Tonelli, M., Klarenbach, S., Walsh, M., \& 
Culleton, B. F. (2007). Association between Multidisciplinary Care and Survival for Elderly Patients with Chronic Kidney Disease. Journal of the American Society of Nephrology, 18(3), 993-999. https://doi.org/10.1681/ASN.2006080860.

Jiamjariyapon, T., Ingsathit, A., Pongpirul, K., Vipattawat, K., Kanchanakorn, S., Saetie, A., ... Tungsanga, K. (2017). Effectiveness of Integrated Care on Delaying Progression of stage 3-4 Chronic Kidney Disease in Rural Communities of Thailand (ESCORT study): A cluster randomized controlled trial. BMC Nephrology, 18(1), 1-10. https://doi.org/10.1186/s12882-0160414-4.

Pagels, A. A., Hylander, B., \& Alvarsson, M. (2015). A Multi-Dimensional Support Programme for Patients with Diabetic Kidney Disease. Journal of Renal Care, 41(3), 187-194. https://doi.org/https://dx.doi.org/10.1111/jorc.12114.

Peeters, M. J., van Zuilen, A. D., van den Brand, J. A. J. G., Bots, M. L., van Buren, M., ten Dam, M. A. G. J., ... Wetzels, J. F. M. (2014). Nurse Practitioner Care Improves Renal Outcome in Patients with CKD. Journal of the American Society of Nephrology, 25(2), 390-398. https://doi.org/10.1681/ASN.2012121222.

The Joanna Briggs Institute. (2016). Checklist for Systematic Reviews and Research Syntheses. The Joanna Briggs Institute. Retrieved May 3, 2018 from http://joannabriggs.org/research/critical-appraisal-tools.html diakses 3 Mei 2018.

Webster, A. C., Nagler, E. V., Morton, R. L., \& Masson, P. (2017). Chronic Kidney Disease. The Lancet, 389(10075), 1238-1252. https://doi.org/10.1016/S01406736(16)32064-5.

World Health Organization. (2015). Mortality and global health estimates: Causes of death; Projections for 2015-2030; Projection of death rates. Retrieved May 9, 2018, from http://apps.who.int/gho/data/node.main. PROJRATEWORLD?lang=en diakses 9 Mei 2018. 